\title{
THE (RE)PRODUCTION OF MERITOCRACY: CHALLENGES FROM THE ROMANIAN HIGHER EDUCATION SYSTEM UNDER NEOLIBERALISM
}

\begin{abstract}
ALEXANDRU GAVRIȘ1
ABSTRACT. The paper follows the institutionalization of meritocracy in the Romanian higher education. Using the Romanian experience, the study explores the setting of meritocracy, highlights the revised institutional genesis that led to the adoption of a so-called post-traditional approach, and it reviews the deployment of practices that steered higher education in Romania. In support to these, a reflective stance is employed alongside secondary sources to scrutinize the techniques of control and practices which inform institutional evolution. The research attempts to shed light on the increase of doctrinal entrenchment through which meritocracy justifies academic stratification in a pauper system aspiring to world-class recognition.
\end{abstract}

Keywords: meritocracy, higher education policy, Romania, neoliberalism

\section{Introduction}

Interventions in higher education (HE) have embraced the umbrella of neoliberalism (Doherty, 2015) mobilizing discourses of excellence and marketization by extending the logic of competition (Littler, 2018). They embody a powerful strategy that aspires to reinvent the university (Marginson and Considine, 2000) and to proliferate the knowledge capitalism (Olssen and Peters, 2005). When it comes to analyse such directions, meritocracy has gained an increased attention in education, meritocracy being employed to shape the system as an institutional construct (Mateos-González and Boliver, 2019). Aiming to use merit as a link between education and labour (Souto-Otero, 2010), HE policies have pursued social justice and social mobility (Lim and Tan, 2018). On the other hand, these have eroded the base of human relations (Purcell, 2007; Liu, 2011; Littler, 2013; Mijs, 2016) that support the university as a key institution.

1 Department of Tourism and Geography, The Bucharest University of Economic Studies, e-mail: alexandru.gavris@rei.ase.ro. 
Romanian higher education (RHE) system is no exception to meritocracy advancements, as it has adopted a strategy of rebuilding itself under the pressures of an extremely state-centric model (Dobbins, 2011). The RHE has triggered institutional measures aimed to reorganize the system through meritocracy by pushing forward the research model through income diversification, incentives and performance criteria. These directions have targeted: academic career, decision making, quality assurance and funding. They have become embedded into a so-called "post-traditional approach meant to be meritocratic" (Vlăsceanu and Hâncean, 2015: 188) to accomplish a fundamental institutional objectiveuniversity's prestige (Maassen, 2017). The approach, however, has failed to grapple the adaptation to what it should have stirred a superior governmentality through merit. Alongside attempting to produce merit, the approach has triggered a maladaptation that mirrors a self-claiming prestige through adaptation to rankings by leading their members to publish in journals barely meeting academic honest standards (Djuric, 2015), pay to be published, receive "international" prizes (Micu, Miclăuș and Ancu, 2018) or devise complex criteria to allow deceptive promotions (Geven and Maricuț, 2015).

Assuming a reflexive perspective, this paper scrutinizes the development of meritocracy as an institutional vector for power and stratification, dominating the period after 2000 in Romania. RHE represents a worthy case to investigate, not just for what it can teach us about a specific context, but also for offering a useful perspective to develop our understanding of meritocracy more generally. RHE context allows connections to a major issue of the HE research, namely the need of analysis upon the intended goals and the unclear effects produced by reforms (Fumasoli and Stensaker, 2013). This calls for critique to expose the directions HE took in less studied spaces. Comparative studies and those focused on Romania have scrutinized the system (Dobbins and Knill, 2009; Dobbins, 2011; Deca, 2015; Dakowska and Harmsen, 2015; Králiková, 2016; Sabic, 2016), yet there are no discussions about meritocracy as part of the reforms. Echoing Lim and Tan (2018), the paper examines meritocracy as a negotiated ideology associated to an allegedly just system and discusses meritocracy as a veil that deceives with rewards based on the interests of the market and the scarcity of the system. It suggests that the adopted meritocratic path might have been created symbolically alongside rhetorical strategies selected to control funds and augment hierarchies.

What follows showcases how meritocracy has emerged and shifted discourses and forms. After presenting methodology, the paper contextualizes the RHE design and by questioning the practices that surround meritocracy, it examines the revised foundations of reforms and their effects. These inform the deployment of practices centred on the (re)production of a meritocratic academic system. Final remarks draw on the establishment of meritocracy as a state-supervised platform. 
THE (RE)PRODUCTION OF MERITOCRACY:

CHALLENGES FROM THE ROMANIAN HIGHER EDUCATION SYSTEM UNDER NEOLIBERALISM

\section{Envisioning Meritocracy}

As a term, meritocracy evolved from the sociology circles in the United Kingdom. Back then, meritocracy implied referential critique (Floud, 1956; Fox, 1956; as cited in Littler, 2013) on expression and context framing a socialdemocratic awareness on the topic. The concept gained prominence through a work of fiction (Young, 1958), but as the book was misread (Donovan, 2006) and the term migrated outside academia, the meritocracy form shifted, becoming norm and vessel of political and economic interventions. These changes emerged within the USA culture where merit related to the functional requirements of the society. Arriving at a result of overemphasising the positive aspects, it pinpointed that advancement and justified reward had to be earned based on inborn traits and individual effort, with the organization ensuring equal chances.

The new form of meritocracy received a boost by being altered once again in the UK. Finding support during the Thatcherism period, meritocracy informed successful consumption (Littler, 2013). Basically, meritocracy developed as a function of accumulation through which population joined the neoliberal shift. Through the 1990s, the meaning of meritocracy rendered in equality of opportunity, a direction preserved for most of the subsequent years. Then, engineered by the British government to support competition, meritocracy accommodated individualism as a path to entrepreneurialism, while still making people believe in merit conceived in a traditional manner (Allen, 2014). As the author states, holding to original definition, meritocracy promoted a void space created by the idealization of justice and the suspension of social cooperation. The neoliberal culture of entrepreneurialism filled this space and used meritocracy as a vector of success.

Several directions inform the success of meritocracy. In the public and political discourse, meritocracy enhances democracy in administration by limiting corruption and inducing good governance (Charron et al., 2017). Economic growth and policies also amend meritocracy as a measure of progress. Coupling meritocracy to the creative class boosted the interest, advanced the economic emphasis and its integration into mainstream discourses targeting job activities. Hence, the positive part of meritocracy developed as a check point for the justice of institutions, seen as necessary for "preventing self-loss and subsequent dissatisfaction" (Allen, 201: 380). Under these directions, the term inflated, but it neglected prior critiques that showed meritocracy was an incompatible relation to the free market logic (Souto-Otero, 2010 commenting Heyek's perspective on the topic). Hence, meritocracy fortified during the ideological expansion of neoliberalism, striving to enhance-paradoxically-egalitarian values under a stratified vision of the society. 
The appeal of meritocracy revolves generally around its moral legitimation of hierarchies and its apparent ability to optimize the allocation of rewards (Mijs, 2016: 17). For this reason, meritocracy has appealed as a technique of positive power synonymous with market justice (Smith and Matějů, 2012) requiring distributive justice. Others have however advocated thoughtful reflection on grasping meritocracy and its dimensions (Liu, 2011). Through this call for careful inspections, Son Hing et al. (2011) has unveiled that meritocracy leans towards an ideology that legitimises hierarchy and inequality or a combination of them. Littler (2013) has confirmed that meritocracy is a way to extend the interests and powers of elites through rankings of key professions, fields of study and subjects. Consequently, the salience of meritocracy revolves around reinterpretations and modes of change under political and economic discourses that make meritocracy to entail a tautological structure (Littler, 2018). Such a transformation is likely to vitiate the qualities of individuals, disrupt collective work, and link them to power spheres (political, economic or education) that project failures on individuals. It leads to a subversion of the logic of the relevant spheres, among which education appears to be the most challenged one.

While it has been considered to improve social, politic or economic spheres, meritocracy has regained its controversial fame of meaning anything under neoliberalism. It is a significant part of neoliberalism, seen here as the governance of markets (Povinelli, 2011), attempting to change HE through discourses and policies towards economic calculations (Centeno and Cohen, 2012). Indeed, meritocracy is a doctrine that colonizes current transformations of education. Documenting the neoliberal shifts taking place in HE, several authors have revealed transition from exchange to competition, from equality to inequality, from labour to human capital (Berg, Huijbens and Larsen, 2016). Following these, the critique on the HE neoliberalization has disclosed the negative consequences that convert people and knowledge into capital (Fraser and Taylor, 2016). Especially Giroux (2014) has linked neoliberalism with a social amnesia responsible for shallow interactions in an attempt to eliminate any critical progress, with education as the main opposing bastion. Similar attacks have made others argue that universities have developed barbaric mutations under the spectrum of "meritocratic extremism" (O'Sullivan, 2016). The reinvention of the university as an enterprise (Marginson and Considine, 2000) is therefore continuously reproduced under the neoliberal agenda. Such a context allows this paper to pinpoint the urgency to explore other contexts where meritocracy is diffusing, the case of RHE contributing to that. 


\section{Methodology}

Considerable discussion circumscribes around the positivist direction and the replication of studies. In this paper we discard such an approach that obscures the critical endeavour (Lefebvre, 2014). Instead, we think that valuable contribution materializes when commenting the techniques of control and practices that "disclose the cognitive means and procedures and the social forms or relationships through which ideals are developed and stabilized into the conventions that we call institutions" (Hasselbladh and Kallinikos, 2000: 707). The contribution therefore emphasises what construes HE as practices of everyday life where meritocracy (re)produces.

Supported with secondary sources, the path relies on reflexive inquiries to criticize the nexus of structures and relations that infused the development of meritocracy. Although a problematic approach, reflexivity helps to improve clarity over the topic and addresses obscured practices as it is the self-replicating clientele system hidden under reinvented meritocratic norms and discourses. It sets the topic within the "most unlikely case study" (Gerring, 2007), a rationale informed by what we know best and can channel through the international literature. By using the described path, we trace the local insetting of RHE meritocracy under a post-traditional transformation.

\section{Revisiting the Institutional Genesis}

The Central East-European (CEE) countries reflect an evolution of contrasting perspectives over the university's role as the main component of HE system reforms. Yet, a common feature reveals universities employed reforms, increased institutional integration and performance. All countries in the region adhered to an extended design framed to depart from the state authority, but taken with measure (Dobbins and Knill, 2009). The exceptionRomania-became a classical case of isomorphism that steered the most its governance towards marketization (Dobbins and Knill, 2009). RHE envisioned the institutional implementation of meritocracy in universities, an attempt which we illustrate from its inception. The inquiry, therefore, explores the state governmentality under the vector of meritocracy. 


\section{Inception}

The reforms of the RHE started soon after the 1989, when Romania saw the opportunity to align to the institutional changes preached in the region and interpreted as beneficial towards international integration and convergence. The difficulty of adaptation originated in the inertia of preserving the state control over HE and breaking the monopoly of conservative forces. Without clear norms, academics controlled hierarchies through age equalled with experience and political/organizational influence, exerting their authority over the evolution of the system. Anchored in the communist tradition of ideological meritocracy (disguised through fierce competition under the Communist Party command), few changes materialized early on. This inertia had profound effects that established an insecure foundation within the reconstruction of RHE. Primarily, it shaped neoliberal radical reforms (Gog, 2015) as the main solution to solve the apathy of the system and sanitize it from its past problems, aiming to reactivate its people by not being looked at as laggards (Dobbins, 2017).

Relaunched in 1998 (Nicolescu, 2002), the reformation comprised interventions focused on decentralization and autonomy. The institutional redesign of RHE expanded throughout tensions between the adepts of extreme transformation and the actors settled around a system of self-preservation. With a basis of reforms already entrenched into a hybrid stage that borrowed neoliberal ideas to shape traditional development (Ban, 2016), it was easy to import neoliberalism with Anglo-American instruments (Dobbins, 2017) and supranational ideas of hegemonic structures and later connect them to European expert organizations. While sketchy, these ideas legitimated contradictory authority and activated subsequent changes. Zealotry (changing whenever possible everything related and coming from communism in the neoliberal directions) and interventionism (facilitating design) framed a common agenda around topics and ideals from above translated locally within "visions of reform" coupled to transition mythologies and ideologies of salvation (Mincu and Horga, 2010).

\section{Pulsations}

Extreme design operated remorseless after 2007. Through the consensus of actors gravitating around HE, all parties agreed-with lax opposition-on the directions and goals set by the "National Pact for Education" (involved for shaping the 2011 Law of National Education). Supported by a strong neoliberal alliance of politicians, economists and intellectuals, the reform accelerated practices 
that envisioned RHE as "the most far-reaching expression of entrepreneurialism" (Dobbins and Knill, 2009: 419) and established intricate rules (Geven and Maricut, 2015) of shaping the meritocracy of the system. The reform exacerbated the neoliberal path RHE took, altering with differentiated effects its structure under a contradictory image between discourse and implementation. Thus, meritocracy became pivotal in RHE through discourses of excellence and new academic elite formation.

However, problems that combine excellence and equality emerged. To accomplish the legitimation of behaviour, RHE established structures of development to overcome limited and poorly managed financial resources, and comply with international commitments. From this position, institutional design could be easily invoked through discourses targeting merit that reinforced other approaches- "the Romanian experience teaches us that diversification policies in reality act as vessels for legitimizing other changes, such as in the public financing of higher education, usually favouring those institutions that are considered to be more competitive" (Sabic, 2016: iv). That became entrenched into the neoliberal actions of the Romanian state in general and local actors in particular interested to produce competition within the HE system.

The new agents of local design (RHE institutions and their leaders) emerged under the common narratives (competition, ranking, autonomy and accountability). Although much of their endeavour receded under political negotiations, they pursued a statistical performance in an attempt to raise the system. Supporting this reasoning comes a statement of one of the first who drafted the reformation, who argues that education illustrates "a hybridity between a production line and a sport competition" (Bîrzea and Fartușnic, 2003: 84). Alongside supra-national and private actors, the new agents created a transverse set of governmental interactions, partly explored by Szakács (2018). Their interactions might have just re-created "academic oligarchs" dressed in new institutional and elitist ranks using the design as a primitive accumulation of political and social capital. It is what Offe (1996) substantiated about the excessive alteration in designing institutions under radical liberalism which then triggers unintended effects.

The accelerated pace and imprinted habits of the new elites confronting the old ones created an elastic transformation under the state bias towards prestige. Through "elastic transformation" we imply the negotiations and the acceptance of strong interventions coupled with the introduction of biased proposals at various levels, which are common elements in Romanian politics and education. At one end, the elasticity stretched under the fight for positions in the newly created institutions, each representative claiming more meritocracy. On the other side, ministerial status involved isomorphic behaviour under a personal view 
on organizational myths that evolved to the current status of a post-traditional academic society meant to be meritocratic. These are parts of a system where each minister (29 in 30 years) attempted a distinctive design and a personal rhetoric framed within the elasticity of political assemblage. The elastic transformation was therefore the mode of RHE to use power and impose authority by gaining support from the system components, adding this to the other mode, which is the reference to international context.

\section{Form}

Transformation of RHE reveals that its institutional design entailed common agents striving towards marketization and internationalization. Although similar characteristics challenged HE throughout the world (Roggero, 2011), their evolution in Romania transformed the RHE into one of the systems most prone to marketization (Dobbins, 2011). Under the assumed recommendations of European Higher Education Area, the RHE reinforced its design uniqueness as the national perspectives bent under the power of transnational ideas (Sabic, 2016). Notably, Szakács (2018: 220) overviewed the institutionalization of Romanian education as an adaptable script of national interests through worldwide discourses of nationhood and citizenship, supplemented with the institutionalization of Europe as a cultural resource, in an attempt to match the vision of a "good society" entailing meritocracy. As much as it was willing to borrow the international expertise disguised under local interests ${ }^{2}$, the Romanian state re-emerged as the main agent shaping the HE (Sabic, 2016; Dobbins, 2017) towards more marketization. It comes with no surprise as Romania embraced neoliberalism (Ban, 2016) regarded as a political power shaping society under the principles of a market economy (Foucault, 2008:131), and through this, the most manipulated sector might have been that of education given its potential to steer the economy and society.

Guided by goals of excellence and performance matching communism, when Romania pursued rankings of productivity, yet anchored in local complications (Ives and Bădescu, 2015; Králiková, 2016), the design of RHE transitioned towards controlling reward and punishment (Gog, 2015; Sabic, 2016). These cemented the RHE re-design, accentuating universities and HE use as political instruments and less as institutions. It increased the view that "the organizational structures of higher education reflect political institutional frames rather than

2 Many HE projects of WB, UNESCO and other institutions were de facto appropriated by Romanian teams, under a lax guidance of international experts. 
educational ones" (Meyer et al., 2007: 195). Nevertheless, the same paradigm of control over the process and product of HE has remained active despite the deceptive retreats of the state from the canvas of design. Actually, because of the complex assemblage operating in Romania, the state has reaffirmed itself as the mastermind shaping the institutional expansion of the RHE. It is also a consequence of missing defensive positions from the universities themselves, not able to articulate convincing narratives about their roles and reimagined adaptation to society (Kwiek, 2012), as actors aspiring to meritocracy.

What the state did with the RHE is an institutional identity shift towards enhancing governmentality under the meritocracy mechanism, translating its prescriptive view on education to facilitate internationalization and liberalization. As radical as it was envisioned, the design could not entirely dissociate from the institutional fabric established during communism (Dobbins and Knill, 2009). It mainly followed institutional isomorphism, enhancing processes driven by legitimacy and the compliance of university to the broader framework of norms and rules. Against this view, Králiková (2016) emphasised the logic of appropriateness which manifested internally in the reform process, arguing that the design emerged as a reaction to the past within a critical juncture at the dawn of transition when new institutional legacies formed and took control over the process. Both accounts therefore substantiated parts of the same design evolution by providing explanatory values to the complex fabric that $\mathrm{HE}$ is. As statist legacies mingled within the new framework, the neoliberal reactions against the system entrenched the actors who attempted to design the HE. The evolution happened as the state has never abandoned its legacies despite apparently allowing larger agency. It is what the next section will discuss under the vector of meritocracy.

\section{A critical interpretation of the RHE meritocracy}

Young (1958) foresaw meritocracy will become a central tool aiming to transform education and integrate it into a market-based society. In Romania, the institutionalization of meritocracy and its design involved deployment of practices and registers capable to steer HE towards the "post-traditional approach". To capture the extent of practices envisioned as meritocratic, we detail individuals' careers, university alliances and management of meritocracy through a context-based critical approach. 


\section{Individual Meritocracy}

In the "post-traditional education", career change turned to activate individuals towards education seen as a private good. Meritocracy has served to break the career advancement lethargy and promote research-focused professors. Several career actions involved extracting the best out of Romanian academics. Subjects had to be redirected from their focus on teaching to research intensive directions. This process extended their norms to make professors compete for a decent wage, yet the time frame expanded over the regulations. Normally in a neoliberal framework, aside teaching and administrative tasks, a Romanian professor has to apply for grants, but their completion enforces extra hours of work, carefully reported through neoliberal technologies- 'minutes' (which frame the overload), enabling management of merit and control over the everyday life. Simply, the Romanian academic had to volunteer his or her free time for the betterment of the system, while the university reported the performance and managed the increase in merit.

The meritocracy of individuals was recreated softly in hard-wired procedures to pursue excellence. Through accountable scripts and bureaucratic measures (Geven and Maricuț, 2015), meritocracy enables selections of subjects who align to normalized qualifications. They much publish in journals with problems, yet institutionally supported, pay or negotiate to become publishable, aim to obtain diplomas and certificates of outstanding activities offered to increase merit, and do "voluntary" activities among other examples. These sorts of qualifications add to the merit manipulation through incentives offered to support the directions set by the institutional apparatus in an effort to enhance meritocrats and to create the illusion of belonging to a special category, differentiating themselves as the new breed of neoliberal regulations. Basically, academics are actively manipulated to consider their merit as their "gold star" reward on behalf of the university, rather than the source of their individual hard work and academic prowess. Meritocracy therefore frames merit as a currency negotiated to acquire "measurable" points and allow entrance to the upper tiers where subjects have to continuously bargain the rate of exchange. The success is locally negotiated within bureaucratic procedures and on most occasions defeatism installs or subjects select one side of the elastic transformation.

Indeed, individualisation by manipulation is a result of the current institutional changes. The focus on competition and research assists the idea that it is the only way to build hyper-capable individuals, capable of a meritocratic university. Above all, in the RHE, this would phase out the undesirable subjects, or at least discipline them. The remnants will be free to act on the academic market, designed to bridge the idealized free market. They will enhance the quality of 
research and flagship the quality of RHE. As parts of the international market, reformed subjects will not burden/shame the system, as they will be capable to financially support academic life. They can shape the "post-traditional approach" and be part not only of the local meritocracy, but will also challenge the international arena.

\section{Management and Meritocracy}

The adoption of neoliberal values in Romania sees managers adjust themselves to the projection of old interests and practices negotiated within the academic community of the new market directions. From the managerial positions, meritocracy needs advertisement because it supports the organizational agenda for displaying success, and it confirms the managerial team as praiseworthy. The advertisement of the organizational management is reinforced with many displays of power: announcing meritorious subjects as part of management achievements, taking photos alongside meritorious subjects, informing the community about the success of different grants, and popularizing events. These practices of displaying meritocracy enhance symbolic forms that serve as "organizational myths" (Meyer and Rowan, 1977), embedded into rituals of power.

When the already under-financed grants competitions are cancelled or the contracted funds are cut and redirected, alternatives to push up the merit rely on distinct schemes of involvement (Redacția, 2014). A grant director has to hire bureaucratic personnel and managers from within the organization raising the merit points of such key actors several times by only occupying relevant duties and conveying authority. Hence, the top tier administrative staff wages escalate to numbers similar to those of private managers from foreign companies. Concurrently, the grants directors and activities coordinators have to master the administrative-financial nexus of the university (obtaining countless signatures and approvals allowing the university bureaucrats to claim a role), where they have to provide additional benefits to the organization by involving once again the bureaucratic staff who, usually, represent the base for selecting agents of design and control.

The development of rationalisation and systematisation advances strategies that equip elites with tools of control and alliance formation under a meritocratic agenda targeting redesigned institutional authority. The strategies manifest through distinct forms of codification (administrative participation, quality assurance, experts creation, etc.), enabling idealized narratives (excellence, Europeanization of education, mobilities, employability among others) purported 
as vital in (re)producing a superior system. There, the focus transfers to university apparatus able to codify merit and deliver it in forms that bind subordination through the recreated hierarchy that strengthens authority. For example, to apply for grants, one has to submit the proposal to the university obtaining first the necessity approval and only then one might apply to the grant competition.

Another situation links to the "allocation of merit" through wages where one has to compete for an extra income ( $\sim 25 \%$ of base wage). Here the competition develops between academic functions, where administrative duties prevail, enforcing allegiances to a group of interests linked to managerial positions. It discloses how merit is still part of a clientele culture disguised under the veil of accountability and meritocracy.

Institutional authority therefore, represented by managers, increases through the alteration of individual merit towards the collective acceptance to meritocratic interests where accountability and managerialism prevail.

It can be inferred that managers enable biopolitics development through meritocracy. They encourage marketing and publicity of career path development. The subjects become storytellers of merit, "of their lives as if they were the outcome of deliberative planning and choice" (Gill, 2016: 42). They are urged and shaped through institutional directives to transfer their professional identity, their experiences and expertise from what they aspire to as researcher and teachers to what authority imposes them to be, for the deemed benefit of the market and society. Hence, the social visibility appears as necessary suggesting discipline- "In discipline it is the subjects who have to be seen" (Foucault, 2012: 189).

Academics become entrapped in a regime of performativity focused on the production of public and marketed self. The newsletters of various universities (2017-2019) indicate this. There, subjects display their performances and merits, which reinforce the managerial positions by promoting them internally to the students as well as internationally through their results as deriving from the good management. Having to report levels of academic life, subjects are caught in a new form of management, that of subjects' personality. Furthermore, by rapport to meritocracy and by accepting the management of personality, academics enable variations of auto-exploitation and surveillance mechanisms of their colleagues. Advancing towards the meritocratic tiers, academics force themselves to attain scripted merits and surveillance over the merit of others which has to be not equal with the personal one, but at least superior and by necessity, anchored into the well-designed managerial registers. 
Illustrative is that many who gained superior ranks and overview the new criteria do not comply to them. Regardless of the outcome, the managers prevail; the results of others become theirs.

\section{Meritocratic alliances}

With fragile funding (by law, the whole education sector should receive six per cent of GDP, yet this has never happened in 30 years) and with increased demands, universities accepted the neoliberal change of HE. Under a market logic, universities have to compete to receive supplementary funds due to the classification into research universities, research and teaching universities, and teaching universities. The classification made universities inflate the rankings and design strategies to become primers certified by the nomination into the second group, which is seen as the most sustainable for their existence. Yet, the allocation of financial resources and the increase of prestige have been heavily hit by legislative interventions that have devised ways of "rationalizing costs, disciplining labour and instilling competition" (Gog, 2015: 28). Hence, the envisioned excellence through competition has suggested a disguised language of meritocracy that has created a tournament policy, permeated by the institutional meritocratic ranking system.

Another part concerns the creation of an elite network of universities. Five universities formed the University Network (Consorțiul Universitaria), a union striving to marshal meritocracy based on their heritage, popular perception and research outputs. Among many aspirations, this union strives towards keeping the flagship of RHE. Given a political decision to receive less budgeted places than other universities perceived as "local/regional" (UBB, 2018), the consortium took a meritocratic stance to separate itself from the rest. Considered the base of academic life in Romania, these universities stressed their role in international science and local development while other universities, notably those developed after 1990, were particularized by the union as having a "local/regional importance" and were contrasted through their adherence to political schemes. The document also lamented the lack of national awards received despite the "visibility/impact" traditional universities have. The point of this lamentation, somewhat justified, was the demarcation created against other units and the over-articulation of the historic legacy. This suggests that policies of extreme competition and the appeal to meritocracy dismantle the system and enhance the neoliberal path of RHE. 
One final example of meritocratic alliances is the NGO Ad Astra association. Alternative to the contested national parametrization of merit, $\mathrm{Ad}$ Astra develops its own ranking of universities and offers symbolic prizes for researchers to highlight what they consider an impartial overview over Romanian science. With good critical insights on the development of RHE, the group, however, fails to see its own problems created by the focus on neoliberal criteria. As such, if one publishes in contested journals and is part of research grants based on subjective qualifications, that person can easily join the organization with little verification in this regard. Moreover, the association appears to have established a neoliberal deviation reinforcing meritocracy by requiring additional status reconfirmation through its own designated criteria. Even the titling "Asociația cercetătorilor români" (the Romanian Researchers Association)- conveys that only its members are the "genuine"/"Romanian" researchers.

\section{Reflecting on meritocracy}

Having framed three directions that support the establishment of the post-traditional meritocracy, this section expands onto the meritocracy discourse.

As pinpointed by the three directions developed within the neoliberal path and the adaptation of academic values to it, meritocracy has encroached merit. It has formed a veil that has deceived with rewards based on the interests of the market and constrains the scarcity of the system. It has enabled commodification while university has lost from its critical position constructed through intellectual endeavour and scrutiny beyond the market forces. This way, meritocracy has portrayed a powerful tool that not only justifies quality but has allotted punishments under discriminatory measures. Under this change, meritocracy has borrowed political and market language, distorting merit semantically and the circumstances that have created it-education where, despite flaws, had points of assessment.

Without a clear reasoning, meritocracy can be everything and this has opened ways to contradictions. It is a container of discourses and registers used to cover up inequalities and funding selection, while preaching about solving them and enhancing excellence. Likewise, confusion only enhances authority because no one, except the upper tier, may concoct what merit is and under what conditions one may receive it. If there are accepted international features, then those are altered to frame particular interests and advance policies that serve the institutional apparatus. A similar conclusion emerges from an analysis 
on internationalization of quality assurance: "government is seen as the main beneficiary of all evaluation procedures, followed perhaps by the university management to a lesser extent" (Geven et al., 2015: 59).

Subsequent achievements are continuously reframed to serve the illusion of reaching the utopian merit tier. Merit is used to promote change and to recreate groups of interests who can support such transformations and maintain the power in a biased environment. The case becomes a ground for control, disguised within the discourse about meritocracy by which people can change and achieve success. As institutional and organizational management regulates merit, individuals are controlled and appropriated through actions that enable allegiance to an exclusive class centred on meritocracy of interests. Accordingly, meritocracy metamorphoses into a mechanism that enables the advancement of those who conform to a wider spectrum of accountable measures that advance political control. This is produced through the transformation of merit from individual selection to a collective selection that targets groups assumed to be meritocratic by trying to establish them as a distinct class of aspiration. Henceforth, meritocracy manages conditions that legitimize exclusion of undesirable subjects through ranks according to how individuals fit within the institutional design. Looking back, the reform has instilled meritocracy, yet it has also subjugated subjects and institutional components by (re)producing them into commodities.

The tactic is to promote modularity where authority can more easily separate the rankings and stratify the academic population. It is an instrument to exert authority through nudging procedures supervising the managerial and institutional directions. It is a silent violence over the academic community that allowed meritocracy to become an alienated instrument augmented through financial gains targeting academic communities and individuals. In regard to this, the power exerted through the discourse of meritocracy transforms individuals into political and economic tools. Equivalent tools are parts of a delegated surveillance where subjects challenge themselves and reject non-meritorious colleagues, avoiding the blame of sitting temporarily on the right side of ranking. We notice therefore a shift from the soft power of merit towards the hard power features of meritocracy, from dialogue to punitive and restrictive measures, from aspirations to the establishment of excellence groups and subservient communities based on bureaucratic and political interests. These enable a partition into good or bad, into worthy and burdensome, demanding discipline and punishment.

Building institutional authority requires responsive subjects to doctrinal identities/discourses by creating alliances that display and promote the benefits of institutional merit and its hard-acquired status. Meritorious subjects negotiate 
a regime of truth beyond the limits of self. This concurs with how the meritocrats consider morality to be on their side as they are entitled to reward themselves (Young, 2001), or to punish others. Preaching about merit delivers a strategy for power and control (gains popularity and maximizes income), but simultaneously creates a survival strategy (avoids criticism and academic isolation) against critique and failures. It stands in line to what Foucault (2007) broached, that governmentality revolves around political power and projection of interests. Now, meritocracy becomes both the strategy and technology employed to design and support the market.

\section{Conclusions}

This paper has explored RHE under the vector of meritocracy. It has linked to studies aiming to dismantle meritocracy (Liu, 2011; Littler, 2013) or its delusions (Purcell, 2007; Mijs, 2016). Following such studies that have criticized meritocracy, the paper has disclosed the aggression of meritocracy over layers of life in academia through increased control and techniques of removing the "pathological" out of the system. Specifically, it has attempted to elaborate on some effects that meritocracy has triggered, pursuing Dobbins's (2011) call for scrutiny in countries financially and ideologically dependent on the West.

The use of meritocracy in the RHE has become the vessel of institutional design in an attempt to move the system up in the rankings. Despite the early warnings of theoreticians who studied former communist countries, the RHE has restructured itself into generating outcomes by relying "on cognitive and moral resources which in their turn, however, are not to be created by administrative fiat" (Offe, 1996: 202). In this regard, the personal level has gained renewed insights through the interest on the stratification of lives because this enables meritocracy to twist morality and alter the university foundation, limiting the empowerment of communities and individuals under neoliberal forces. The research therefore advances a tragedy of the commons when HE is increasingly perceived to gravitate towards a unimodal existence- the neoliberal society advocating meritocracy.

Developed as a reflexive approach, the study also contributes to unveil meritocracy when the state develops into a platform for driving the HE system towards marketization. Disclosing this, we notice that Allen's (2011) prediction about the state governmentality has failed: it is higher and more brutal, just better disguised. At least this is the case in Romania and it would be interesting to be explored in the CEE region too. Another point argues that meritocracy reflects the state power in need of radical institutional design to enhance governmentality 
over its subjects and deliver them into the market. In numerous ways the state channels authority through tools and discourses that stratify academic life, and extends them into the everyday life. The RHE case thus supports the view that "the state has increasingly acquired for itself a new range of scales from which to act, as well as new tools and means of governing" (Robertson, 2012: 48), of which meritocracy stands at the forefront.

Anchored in neoliberal perspectives that have only pushed forward survivalist techniques, the HE has to distance itself and allow a reimagined normality. If the HE strives for quality and sustainability, the alternatives need collective thinking (Feldman and Sandoval, 2018). Old discourses that set the base of HE should be revisited alongside examining new avenues of struggle to improve the life of the community, society and the system. They should allow us to reclaim HE through critical reflection and activism (Morley, MacFarlane and Ablett, 2017). Although meritocracy in HE will hardly collapse, at least merit has to undertake a sustainable course, a more communitarian perspective filtered through collective practice.

\section{REFERENCES}

Allen, Ansgar (2011). Michael Young's the Rise of the Meritocracy: A Philosophical Critique. British Journal of Educational Studies 59(4): 367-382.

Allen, Ansgar (2014). Benign Violence: Education in and Beyond the Age of Reason. Basingstoke: Palgrave MacMillan.

Ban, Cornel (2016). Ruling Ideas: How Global Neoliberalism Goes Local. New York: Oxford University Press.

Berg, Lawrence D, Huijbens, Edward H and Larsen, Henrik Gutzon (2016). Producing Anxiety in the Neoliberal University. The Canadian Geographer/le Géographe Canadien 60(2): 168-180.

Bîrzea, Cesar and Fartușnic, Ciprian (2003). Reforming the Romanian System of Education: The Agenda Ahead. In: Anchan, John P., Fullan, Michael, and Polyzoi, Eleoussa (eds.) Change Forces in Post-Communist Eastern Europe. Education in Transition. London: Routledge, pp. 74-93. DOI: 10.4324/9780203426500-12.

Centeno, Miguel A. and Cohen, Joseph N. (2012) The Arc of Neoliberalism. Annual Review of Sociology 38(1): 317-340. DOI: 10.1146/annurev-soc-081309-150235.

Charron, Nicholas; Dahlström, Carl; Fazekas, Mihaly, et al. (2017). Careers, Connections, and Corruption Risks: Investigating the Impact of Bureaucratic Meritocracy on Public Procurement Processes. The Journal of Politics 79(1): 89-104. DOI: $10.1086 / 687209$. 
Dakowska, Dorota and Harmsen, Robert (2015). Laboratories of reform? The Europeanization and internationalization of higher education in Central and Eastern Europe. European Journal of Higher Education 5(1): 4-17. DOI: $10.1080 / 21568235.2014 .977318$.

Deca, Ligia (2015). International Norms in the Reform of Romanian Higher Education: A Discursive Analysis. European Journal of Higher Education 5(1): 34-48. DOI: 10.1080/21568235.2014.971040.

Djuric, Dragan (2015). Penetrating the Omerta of Predatory Publishing: The Romanian Connection. Science and Engineering Ethics 21(1): 183-202. DOI: 10.1007/ s11948-014-9521-4.

Dobbins, Michael (2011). Explaining Different Pathways in Higher Education Policy in Romania and the Czech Republic. Comparative Education 47(2): 223-245. DOI: 10.1080/03050068.2011.555116.

Dobbins, Michael (2017). Exploring Higher Education Governance in Poland and Romania: Re-Convergence after Divergence? European Educational Research Journal 16(5): 684-704. DOI: 10.1177/1474904116684138.

Dobbins, Michael and Knill, Christoph (2009). Higher Education Policies in Central and Eastern Europe: Convergence Toward a Common Model? Governance 22(3): 397- 430. DOI: 10.1111/j.1468-0491.2009.01445.x.

Doherty, Catherine (2015). Tracking the Neoliberal Juggernaut: A Virtual Edition. Critical Studies in Education 56(3): 395-401. DOI: 10.1080/17508487.2015.1066819.

Donovan, Claire (2006). The Chequered Career of a Cryptic Concept. The Political Quarterly 77: 61-72.

Feldman, Zeena and Sandoval, Marisol (2018). Metric Power and the Academic Self: Neoliberalism, Knowledge and Resistance in the British University. Triple C: Communication, Capitalism \& Critique. Open Access Journal for a Global Sustainable Information Society 16(1): 214-233.

Floud, Jean (1956). Sociology and Education. The Sociological Review 4(S1): 57-67. DOI: 10.1111/j.1467-954X.1956.tb03372.x.

Foucault, Michel (2007). Security, Territory, Population: Lectures at the Collège de France, 1977-78. Basingstoke: Palgrave Macmillan.

Foucault, Michel (2008). The Birth of Biopolitics: Lectures at the Collège de France, 19781979. Senellart, Michel; Ewald, François, and Fontana, Alessandro (eds). Basingstoke: Palgrave Macmillan.

Foucault, Michel (2012). Discipline and Punish: The Birth of the Prison. New York: Vintage.

Fox, Alan (1956). Class and Equality. Socialist Commentary: 11-13.

Fraser, Heather and Taylor, Nik (eds.) (2016). Neoliberalization, Universities and the Public Intellectual: Species, Gender and Class and the Production of Knowledge. London: Palgrave Macmillan.

Fumasoli, Tatiana and Stensaker, Bjørn (2013). Organizational Studies in Higher Education: A reflection on Historical Themes and Prospective Trends. Higher Education Policy 26(4): 479-496. 
THE (RE)PRODUCTION OF MERITOCRACY:

CHALLENGES FROM THE ROMANIAN HIGHER EDUCATION SYSTEM UNDER NEOLIBERALISM

Gerring, John (2007). Case Study Research: Principles and Practices. Cambridge: Cambridge University Press.

Geven, Koen and Maricuț, Adina (2015). Forms in Search of Substance: Quality and Evaluation in Romanian Universities. European Educational Research Journal 14(1): 113-125. DOI: 10.1177/1474904114565151.

Geven, Koen; Sârbu, Oana; Santa, Robert, et al. (2015). Why do Romanian Universities Fail to Internalize Quality Assurance? In: Curaj, Adrian; Deca, Ligia; Egron-Polak, Eva, et al. (eds.) Higher Education Reforms in Romania: Between the Bologna Process and National Challenges. Cham: Springer, pp. 43-61. DOI: 10.1007/9783-319-08054-3_3.

Gill, Rosalind (2016). Breaking the Silence: The Hidden Injuries of Neo-Liberal Academia. Feministische Studien 34(1): 39-55. DOI: 10.1515/fs-2016-0105.

Giroux, Henry A (2014). Neoliberalism's War on Higher Education. Chicago, Illinois: Haymarket Books.

Gog, Sorin (2015). Competitiveness and Research-Oriented Teaching in Romanian Universities: The Neo-Liberal Transformation of the Higher Education System. Studia Universitatis Babeș-Bolyai Sociologia 6(1): 23-62.

Hasselbladh, Hans and Kallinikos, Jannis (2000). The Project of Rationalization: A Critique and Reappraisal of Neo-Institutionalism in Organization Studies. Organization Studies 21(4): 697-720. DOI: 10.1177/0170840600214002.

Ives, Bob and Bădescu, Gabriel (2015). Romanian Scholarly Productivity: Recent History and Recommendations. Higher Education Research \& Development 34(5): 926-941.

Králiková, Renáta (2016). Transition Legacies, Rules of Appropriateness and 'Modernization Agenda' Translation in Higher Education Governance in Lithuania, Romania and Slovakia. PhD thesis. Doctoral School of Political Science, Public Policy; International Relations; Central European University Budapest. Available at: http://www.etd.ceu.hu/2016/kralikova_renata.pdf.

Kwiek, Marek (2012). Universities and Knowledge Production in Central Europe. European Educational Research Journal 11(1): 111-126. DOI:10.2304/ eerj.2012.11.1.111.

Lefebvre, Henri (2014). Critique of Everyday Life. The One-Volume. London: Verso.

Lim, Leonel and Tan, Michael (2018). Meritocracy, Policy and Pedagogy: Culture and the Politics of Recognition and Redistribution in Singapore. Critical Studies in Education 61(3). Routledge: 1-17. DOI: 10.1080/17508487.2018.1450769.

Littler, Jo (2013). Meritocracy as Plutocracy: The Marketising of 'Equality' under Neoliberalism. New Formations 80(80): 52-72.

DOI: 10.3898/newf.80/81.03.2013.

Littler, Jo (2018). Against Meritocracy. New York: Routledge.

Liu, Amy (2011). Unravelling the Myth of Meritocracy within the Context of US Higher Education. Higher Education 62(4): 383-397.

Maassen, Peter (2017). The University's Governance Paradox. Higher Education Quarterly 71(3): 290-298. DOI: 10.1111/hequ.12125. 
Marginson, Simon and Considine, Mark (2000). The enterprise university: Power, Governance and Reinvention in Australia. Cambridge: Cambridge University Press.

Mateos-González, José Luis and Boliver, Vikki (2019). Performance-Based University Funding and the Drive Towards 'Institutional Meritocracy' in Italy. British Journal of Sociology of Education 40(2): 145-158. DOI: $10.1080 / 01425692.2018 .1497947$.

Meyer, John W.; Ramirez, Francisco 0.; Frank, Davis J., et al. (2007). Higher Education as an Institution. In: Gumport, Patricia J. (ed.) Sociology of Higher Education: Contributions and Their Contexts. Baltimore: John Hopkins University Press, pp. 187-221.

Meyer, John W and Rowan, Brian (1977). Institutionalized Organizations: Formal Structure as Myth and Ceremony. American Journal of Sociology 83(2): 340-363.

Micu, Octavian; Miclăuș, Mihai and Ancu, Lucian (2018). Salonul de Inventică de la Geneva, 'jde premii și țâșpe sute de medalii [International Exhibition of Inventions Geneva, a Chiliad of Prizes and a Throng of Medals]. Available at: https://mic-micanc.ro/2018/04/18/salonul-de-inventica-de-la-geneva-jde-premii-si-taspesute-de-medalii/ [Accessed 18 April 2018].

Mijs, Jonathan J.B. (2016). The Unfulfillable Promise of Meritocracy: Three Lessons and their Implications for Justice in Education. Social Justice Research 29(1): 14-34. DOI: $10.1007 / \mathrm{s} 11211-014-0228-0$.

Mincu, Monica E. and Horga, Irina (2010). Visions of Reform in Post-Socialist Romania: Decentralization (Through Hybridization) and Teacher Autonomy. In: Silova, Iveta (ed.) Post-Socialism Is Not Dead: (Re)Reading the Global in Comparative Education. Bingley: U.K Emerald, pp. 93-123.

DOI: 10.1108/S1479- 3679(2010)0000014007.

Morley, Christine; MacFarlane, Selma and Ablett, Phillip (2017). The Neoliberal Colonisation of Social Work Education: A Critical Analysis and Practices for Resistance. Advances in Social Work and Welfare Education 19(2): 25-40.

Nicolescu, Luminița (2002). Reforming Higher Education in Romania. European Journal of Education 37(1): 91-100.

Offe, Claus (1996). Designing Institutions in East European Transitions. In: Goodin, Robert E. (ed.) The Theory of Institutional Design. Cambridge, England: Cambridge University Press, pp. 199-226.

Olssen, Mark and Peters, Michael A. (2005). Neoliberalism, Higher Education and the Knowledge Economy: from the Free Market to Knowledge Capitalism. Journal of Education Policy 20(3): 313-345. DOI: 10.1080/02680930500108718.

O'Sullivan, Michael (2016). Academic Barbarism, Universities and Inequality. London: Palgrave Macmillan.

Povinelli, Elizabeth (2011). Economies of Abandonment. Social Belonging and Endurance in Late Liberalism. Durham, North Carolina: Duke University Press.

Purcell, Mark (2007). 'Skilled, Cheap, and Desperate': Non-Tenure-Track Faculty and the Delusion of Meritocracy. Antipode 39(1): 121-143. DOI: 10.1111/j.1467-8330. 2007.00509.x.

Redacția (2014). Posdru, suflete moarte [Posdru, Dead Souls]. Available at: http://www.criticatac.ro/posdru-suflete-moarte/ [Accessed 29 January 2019]. 
THE (RE)PRODUCTION OF MERITOCRACY:

CHALLENGES FROM THE ROMANIAN HIGHER EDUCATION SYSTEM UNDER NEOLIBERALISM

Robertson, Susan L. (2012). Researching Global Education Policy: Angles in/on/out... In: Verger, Antoni; Altinyelken, Hülya K., and Novelli, Mario (eds.) Global Education Policy and International Development: New Agendas, Issues and Policies. London: Bloomsbury Academic, pp. 33-52.

Roggero, Gigi (2011). The Production of Living Knowledge: The Crisis of the University and the Transformation of Labor in Europe and North America. Philadelphia: Temple University Press.

Sabic, Norbert (2016). Diversification of Higher Education in Europe. A Policy Narrative that Legitimizes Resource Concentration. PhD thesis. Central European University. Available at:

https://pds.ceu.edu/sites/pds.ceu.hu/files/attachment/basicpage/478/sabicn o rbertpp-dissertation2016.pdf.

Smith, Michael L. and Matějů, Petr (2012). Two Decades of Value Change: The Crystallization of Meritocratic and Egalitarian Beliefs in the Czech Republic. Social Justice Research 25(4). DOI: 10.1007/s11211-012-0164-9.

Son Hing, Leanne S.; Bobocel, D. Ramona; Zanna, Mark P., et al. (2011). The Merit of Meritocracy. Journal of Personality and Social Psychology 101(3): 433-450. DOI: $10.1037 / \mathrm{a} 0024618$.

Souto-Otero, Manuel (2010). Education, Meritocracy and Redistribution. Journal of Education Policy 25(3): 397-413. DOI: 10.1080/02680930903576396.

Szakács, Simona (2018). Europe in the Classroom. World Culture and Nation-Building in Post-Socialist Romania. Cham: Palgrave Macmillan. DOI: 10.1007/978-3-31960258- 5 .

UBB (2018). Scrisoare Deschisă adresată Guvernului României. Universităţile Reprezentative ale României sub Asediu! [Open Letter to the Romanian Government. Exponent Romanian Universities under Assault!]. Available at: www.ase.ro/2013_files/media/Avizier_2018/Newsletter_Universitaria_ aprilie_2018.pdf [Accessed 3 February 2019].

Vlăsceanu, Lazăr and Hâncean, Marian-Gabriel (2015). Policy Incentives and Research Productivity in the Romanian Higher Education. An Institutional Approach. In: Curaj, Adrian; Matei, Liviu; Pricopie, Remus, et al. (eds.) The European Higher Education Area: Between Critical Reflections and Future Policies. Cham: Springer, pp. 185-203. DOI: 10.1007/978-3-319-20877-0_13.

Young, Michael (1958). The Rise of the Meritocracy, 1870-2033: An Essay on Education and Quality. London: Thames; Hudson.

Young, Michael (2001). Down with meritocracy. Available at: https://www.theguardian.com/politics/2001/jun/29/comment [Accessed 9 September 2018]. 